\title{
Biomarkers for determining the prognosis in chronic myelogenous leukemia
}

\author{
Kendra Sweet, Ling Zhang and Javier Pinilla-lbarz
}

\begin{abstract}
The introduction of BCR-ABL1 tyrosine kinase inhibitors (TKIs) for treatment of chronic myelogenous leukemia in chronic phase (CML-CP) has revolutionized therapy, altering the outcome from one of shortened life expectancy to long-term survival. With over 10 years of long-term treatment with imatinib and several years of experience with the next generation of TKIs, including nilotinib, dasatinib, bosutinib, and ponatinib, it is becoming clear that many clinical parameters have great impact on the prognosis of patients with CML. Emerging novel gene expression profiling and molecular techniques also provide new insights into CML pathogenesis and have identified potential prognostic markers and therapeutic targets. This review presents the supporting data and discusses how certain clinical characteristics at diagnosis, the depth of early response, the presence of certain kinase domain mutations, and additional molecular changes serve as prognostic factors that may guide individualized treatment decisions for patients with CML-CP.
\end{abstract}

Keywords: Chronic myelogenous leukemia, BCR-ABL1, Philadelphia chromosome, Kinase domain mutation, Imatinib resistance, Tyrosine kinase inhibitors, Prognosis

\section{Introduction}

Chronic myelogenous leukemia (CML) is a clonal myeloproliferative neoplasm caused by constitutive activation of the BCR-ABL1 tyrosine kinase, a result of the $t$ $(9 ; 22)(\mathrm{q} 34 ; \mathrm{q} 11)$ translocation designated the Philadelphia $(\mathrm{Ph})$ chromosome [1]. Treatment targeting this kinase has proven to be highly successful. The introduction of imatinib, the first BCR-ABL1 tyrosine kinase inhibitor (TKI), overturned the treatment paradigm for CML $[2,3]$ by extending survival in patients who maintain durable response to continued imatinib therapy $[4,5]$.

Although imatinib represented a major therapeutic advance, the need for additional treatments was recognized and addressed by the development of the more potent BCR-ABL1 TKIs nilotinib, dasatinib, bosutinib, and ponatinib (Table 1). Nilotinib and dasatinib were approved for first-line treatment of $\mathrm{Ph}+\mathrm{CML}$ in chronic phase (CP) based on results of separate phase 3 studies indicating superior cytogenetic and molecular response rates compared with imatinib [6-9]. Three- and 4-year data from both studies continue to demonstrate significantly

\footnotetext{
* Correspondence: javier.pinilla@moffitt.org

H. Lee Moffitt Cancer Center \& Research Institute, 13131 Magnolia Drive 3 East, Room 3056H, Tampa, FL 33612, USA
}

greater response rates for nilotinib and dasatinib versus imatinib [10-12].

With 3 TKIs currently available for front line therapy and 2 more TKIs for second- and third-line therapy, questions arise regarding which agent should be used, and when, to optimize long-term outcomes. Numerous patient- and drug-related factors, in addition to financial considerations, contribute to decisions on treatment selection. Emerging evidence suggests that certain clinical characteristics at diagnosis, the depth of early response, the presence of certain kinase domain (KD) mutations, and additional molecular changes may impact the prognosis of CML patients. This review examines various prognostic factors in CML and explores the practical utility of these prognostic factors in guiding treatment decisions for patients with CML-CP both now and in the future.

\section{Prognostic indicators at diagnosis}

Prognostic scoring systems. CML prognostic scoring systems stratify patients into risk groups based on patientand disease-related characteristics at diagnosis. Until recently, there were 2 widely used scoring systems, Sokal and Hasford (Table 2). Introduced in 1984, the Sokal 
Table 1 US FDA-Approved BCR-ABL1 TKIs

\begin{tabular}{|c|c|c|}
\hline Name & $\begin{array}{c}\text { Year } \\
\text { approved }\end{array}$ & Indications in $\mathrm{CML}$ \\
\hline \multirow[t]{2}{*}{ Imatinib } & 2001 & $C P, A P$, or $B C$ after failure of interferon therapy \\
\hline & 2003 & Newly diagnosed CP \\
\hline \multirow[t]{2}{*}{ Dasatinib } & 2006 & $\begin{array}{l}C P, A P \text {, or } B C \text { after resistance to or intolerance } \\
\text { of imatinib }\end{array}$ \\
\hline & 2010 & Newly diagnosed CP \\
\hline \multirow[t]{2}{*}{ Nilotinib } & 2007 & $\begin{array}{l}\mathrm{CP} \text { or } \mathrm{AP} \text { after resistance to or intolerance } \\
\text { of imatinib }\end{array}$ \\
\hline & 2010 & Newly diagnosed CP \\
\hline Bosutinib & 2012 & $\begin{array}{l}\mathrm{CP}, \mathrm{AP} \text {, or } \mathrm{BC} \text { after resistance to or intolerance } \\
\text { of prior therapy }\end{array}$ \\
\hline Ponatinib & 2012 & $\begin{array}{l}\mathrm{CP}, \mathrm{AP}, \text { or } \mathrm{BC} \text { after resistance to or intolerance } \\
\text { of prior } \mathrm{TKI} \text { therapy }\end{array}$ \\
\hline
\end{tabular}

$A P$ accelerated phase, $B C$ blast crisis, $C M L$ chronic myelogenous leukemia, $C P$ chronic phase, FDA Food and Drug Administration, TKI tyrosine kinase inhibitor, US United States.

score could classify patients treated with standard chemotherapy (busulfan or hydroxyurea) into 3 risk groups, each with significantly different predicted longterm survival [13]. With wider use of interferon- $\alpha$ for early-stage CML, the Sokal score lost prognostic utility and the Hasford score was developed [14].

In 2011, the European Treatment and Outcome Study (EUTOS) score was introduced to reflect current standard use of first-line imatinib (Table 2) [15]. In a comparative evaluation, the EUTOS score was better than Sokal or
Hasford scores at predicting complete cytogenetic response (CCyR) at 18 months (positive predictive value, $34 \%$; sensitivity, 23\%; specificity, 92\%) and progressionfree survival (PFS) at 5 years (sensitivity, 16\%; specificity, 91\%) [15]. In an analysis of the German CML-Study IV, EUTOS classification (high versus low risk) significantly correlated with achievement of major molecular response (MMR) and complete molecular response (CMR) [16].

Not all groups have been able to validate the EUTOS score, however. An analysis from Hammersmith Hospital of 277 imatinib-treated patients found that Sokal score, but not EUTOS score, predicted overall survival (OS), PFS, CCyR, and MMR [17]. The MD Anderson Cancer Center group showed that EUTOS score was not successful at predicting outcomes (MMR, transformation-free survival, event-free survival [EFS], or OS) in an analysis of CML-CP patients treated with imatinib $(\mathrm{n}=279)$, nilotinib $(\mathrm{n}=98)$, or dasatinib $(\mathrm{n}=88)$ [18]. Disparate conclusions about the utility of the EUTOS score may be due to differences in patient populations evaluated or its inapplicability to patients receiving first-line nilotinib or dasatinib.

The applicability of Sokal and Hasford scores for patients receiving newer TKIs is also unclear. In the Evaluating Nilotinib Efficacy and Safety in Clinical Trials-Newly Diagnosed Patients (ENESTnd) study, nilotinib-treated patients had higher rates of MMR, CMR, and CCyR by 24 months than imatinib-treated patients, regardless of Sokal risk category [10]. Similarly, the

Table 2 Sokal, Hasford, and EUTOS Systems [13-15]

\begin{tabular}{|c|c|c|c|}
\hline & Sokal & Hasford (EURO) & EUTOS \\
\hline $\begin{array}{l}\text { Year } \\
\text { introduced }\end{array}$ & 1984 & 1998 & 2011 \\
\hline $\begin{array}{l}\text { Predominant } \\
\text { treatment } \\
\text { modality }\end{array}$ & Conventional chemotherapy & Interferon-a-based regimens & Imatinib \\
\hline \multirow[t]{6}{*}{ Factors } & -Age & -Age & -Spleen size \\
\hline & -Spleen size & -Spleen size & \multirow{5}{*}{$\begin{array}{l}\text {-Basophil } \\
\text { - count }\end{array}$} \\
\hline & .Platelet count & -Platelet count & \\
\hline & .Percentage of blasts & .Percentage of blasts & \\
\hline & & -Percentage of basophils & \\
\hline & & -Percentage of eosinophils & \\
\hline $\begin{array}{l}\text { Calculation of } \\
\text { score }\end{array}$ & $\begin{array}{l}\text { Exp } 0.0116(\text { age }-43)+0.0345 \text { (spleen size }[\mathrm{cm} \text { below } \\
\text { costal margin] }-7.5 \mathrm{~cm})+0.188\left[(\text { platelet count } / 700)^{2}-\right. \\
0.563]+0.0887(\% \text { blasts in blood }-2.1)\end{array}$ & $\begin{array}{l}(0.6666 \times \text { age }[0 \text { when age }<50 \text { years; } 1 \text {, otherwise }]+ \\
0.0420 \times \text { spleen size }[\mathrm{cm} \text { below costal margin] }+0.0584 \times \\
\text { blasts [\%] }+0.0413 \times \text { eosinophils }[\%]+0.2039 \times \text { basophils } \\
{[0 \text { when basophils }<3 \% ; 1 \text {, otherwise }]+1.0956 \times \text { platelet }} \\
\text { count }\left[0 \text { when platelets }<1500 \times 10^{9} / L ; 1 \text {, otherwise] }\right) \times 1000\end{array}$ & $\begin{array}{l}7 \times \text { basophils } \\
+4 \times \text { spleen } \\
\text { size }\end{array}$ \\
\hline \multirow[t]{3}{*}{ Risk groups ${ }^{a}$} & H High: score $>1.2$ & .High: score $>1480$ & $\begin{array}{l}\cdot \text { High: score } \\
>87\end{array}$ \\
\hline & -Intermediate: score 0.8-1.2 & -Intermediate: score $>780$ and $\leq 1480$ & \multirow{2}{*}{$\begin{array}{l}\cdot \text { Low: } \\
\text {-score } \leq 87\end{array}$} \\
\hline & -Low: score $<0.8$ & Low: score $\leq 780$ & \\
\hline
\end{tabular}

${ }^{\mathrm{a} A n}$ intermediate risk category is not defined for EUTOS. 
Dasatinib versus Imatinib Study in Treatment-Naive CML Patients (DASISION) study found higher 24-month MMR rates with dasatinib versus imatinib across Hasford risk categories [19]. Interestingly, in both the ENESTnd and DASISION studies, patients who progressed in the imatinib arms were categorized as intermediate or high risk patients per the respective scoring systems. In the Bosutinib Efficacy and Safety in Newly Diagnosed CML (BELA) study, patients on bosutinib had higher rates of 12-month MMR than patients on imatinib, regardless of Sokal risk category [20].

These findings suggest that the parameters used in these prognostic scoring systems are limited, mostly clinically oriented, and not directly related to genetic or molecular indicators. Nevertheless, because high-risk patients in the ENESTnd and DASISION studies experienced less disease progression on nilotinib and dasatinib, respectively, than on imatinib, NCCN Guidelines recommend determination of Sokal or Hasford risk status as part of the initial workup and the use of nilotinib or dasatinib in high-risk patients [5]. Further validation of the EUTOS score will also be necessary before it is used in routine practice.

"Real-world" prognostic factors. Most data regarding imatinib use are from clinical studies; data from realworld settings are sparse. A recent study investigated prognostic factors associated with achievement of complete hematologic response, CCyR, MMR, and CMR in 1063 patients on first-line imatinib treatment who had not participated in clinical studies [21]. Low Sokal risk score, age $<45$ years, and African-American ethnicity were associated with better outcomes [21]. How widely considered these specific prognostic factors are in routine risk assessment and whether they are applicable to nilotinib- or dasatinib-treated patients are unknown.

Prognostic impact of additional cytogenetic aberrations (ACAs). ACAs are documented in 10\%-15\% of newly diagnosed patients before TKI treatment [22]. In a retrospective analysis of the German CML Study IV, patients with "major route" ACAs, including an additional $\mathrm{Ph}$ chromosome, trisomy 8 , isochromosome $17 \mathrm{q}$, and trisomy 19 [23,24], at diagnosis had significantly longer median times to CCyR and MMR, and reduced 5-year PFS and OS compared to patients without ACAs [24]. Other studies have demonstrated that CML-CP patients who developed ACAs during imatinib treatment had significantly worse outcomes than patients who did not [25]. The emergence of ACAs during treatment signifies clonal evolution and, by definition, disease transformation to accelerated phase/blast crisis (AP/BC) [26,27]. Current guidelines recommend bone marrow cytogenetic testing at diagnosis, when patients respond inadequately to first-line treatment, and when patients show increasing disease burden [5]. The presence of ACAs, especially major-route abnormalities, at diagnosis may indicate high risk for poor prognosis and may justify the use of a next-generation TKI over imatinib as initial therapy.

Variant translocations. Nearly all patients with CML have a $B C R-A B L 1$ fusion gene from the $\mathrm{t}(9 ; 22)(\mathrm{q} 34 ; \mathrm{q} 11)$ translocation. Approximately $5 \%-10 \%$ of patients, however, have more complex rearrangements involving chromosomes 9, 22, and one or more additional chromosomes [28]. Many variants have been identified, highlighting the genetic heterogeneity of these patients [29-32]. The prognostic significance of variant translocations remains controversial [30,31,33-35], however, and requires further study. Thus, this parameter has not yet been widely applied in treatment decision-making for patients with CML.

BCR-ABL1 transcript: e13a2 (b2a2) versus e14a2 (b3a2). Most mRNAs transcribed from $B C R-A B L 1$ have either an e13a2 or e14a2 junction. Although both mRNAs encode the p210 product of BCR-ABL1 [36,37], the e14a2 transcript positively correlates with response. In one study, patients with the e14a2 transcript achieved higher rates of CCyR at 12 months and achieved CCyR more rapidly than patients with the e13a2 transcript [37]. In another study, MMR and $\mathrm{MR}^{4}(B C R-A B L 1 \leq$ $0.01 \%$ ) were achieved more rapidly by patients with the e14a2 versus the e13a2 transcript [38]. At present, this parameter is not widely used in routine practice, in large part because many commercial molecular testing laboratories do not report the type of $B C R-A B L 1$ transcript. Furthermore, although these data are suggestive, further investigation will be necessary to conclusively determine the prognostic utility of $B C R-A B L 1$ transcript type.

Pharmacokinetics. The organic cation transporter-1 (OCT-1) is the major transporter of imatinib into CML cells [39]. OCT-1 activity, which reflects the degree of imatinib influx, can predict long-term risk of resistance and transformation [40]. Patients with high OCT-1 activity were significantly more likely to achieve MMR by 5 years, and have significantly higher OS and EFS rates and lower KD mutation rates than patients with low activity. Although OCT-1 activity may predict imatinib failure, it is unlikely to affect the response to nilotinib, dasatinib, or ponatinib, as influx of these drugs does not rely on OCT proteins $[39,41,42]$. The effect of OCT-1 acitivity on bosutinib influx is unknown [43]. The measurement of OCT-1 activity level is currently limited to clinical research and is not yet considered routine practice.

Imatinib plasma levels may correlate with treatment response. In one study, mean imatinib trough levels were significantly higher in patients who achieved CCyR and MMR than in patients who did not (1123 versus $694 \mathrm{ng} /$ $\mathrm{mL}, P=0.03)$ [44]. An exploratory analysis from the International Randomized Study of Interferon and STI571 
(IRIS) found that imatinib trough levels predicted rates of CCyR, MMR, and EFS [45]. Some subsequent studies have confirmed these findings; others have not [45-48]. Because the clinical benefit of treatment change based on TKI plasma levels is unproven, current guidelines do not recommend routine monitoring of this sort [5].

\section{Prognosis based on early treatment response: landmark analyses}

Landmark analyses assess treatment responses at fixed timepoints and correlate them with future endpoints or clinical outcomes. Landmark analysis of the IRIS study found that molecular responses at 6,12 , and 18 months predicted outcomes at 7 years [49]. The 7-year PFS rate was $99 \%$ for patients who attained MMR by 12 or 18 months, compared with $90 \%$ for patients who did not. Rates of 7 -year EFS were $95 \%, 86 \%$, and $65 \%$ in patients who achieved MMR, $B C R-A B L 1>0.1 \%$ to $\leq 1.0 \%$ per the international scale (IS), and $B C R-A B L 1^{\mathrm{IS}}>1.0 \%$, respectively, at 18 months [49]. These data suggested that response kinetics are important, with rapid and deep molecular responses predicting excellent long-term outcomes.

In particular, molecular response to TKI therapy at 3 months predicts future molecular response and longterm survival outcomes, including OS (Table 3) [50,51]. In one landmark analysis of imatinib-treated patients, $B C R-A B L 1$ transcript level at 3, 6, and 12 months predicted the 8-year rates of CCyR, MMR, CMR, OS, PFS, and EFS, but only $B C R-A B L 1$ transcript level at 3 months was found to be an independent predictor of 8-year survival outcomes (Figure 1) [51].

Other studies have found evidence supporting the prognostic significance of achieving molecular response at 3 months in patients treated with imatinib, nilotinib, dasatinib, or bosutinib (Table 3). Notably, early responses in these studies were predictive of positive long-term outcomes, irrespective of TKI received. Furthermore, the newer TKIs produced faster molecular responses than imatinib, which is consistent with data from the ENESTnd, DASISION, and BELA trials [7,9,20,22,52-55].

Based on strong evidence that rapid, deep molecular responses predict favorable long-term outcomes, the National Comprehensive Cancer Network Clinical Practice Guidelines in Oncology (version 4.2013) have incorporated, for the first time, a molecular response goal of $B C R-A B L 1 \leq 10 \%$ at 3 months [5]. The newer TKIs are superior to imatinib in eliciting rapid response, but longer-term experience with the newer TKIs in the front-line setting will be necessary to help guide treatment decisions. Furthermore, the NCCN Guidelines recommend that patients not reaching the goal of $B C R$ $A B L 1 \leq 10 \%$ at 3 months be considered for a treatment change-in other words, replacing their current therapy with an alternative TKI. At present, however, the longterm clinical benefit of an early switch in treatment remains under investigation.

\section{Predictive utility of mutational analysis}

Point mutations in the $B C R-A B L 1 \mathrm{KD}$ are a key mechanism of resistance [56]. Most KD mutations acquired during imatinib treatment confer resistance and predict poor prognosis. The presence of KD mutations often portends disesase progression, especially when patients do not respond to second-line TKI therapy. Thus, the NCCN Guidelines recommend that mutational analysis be done when patients show inadequate initial response to TKI therapy, or when there is evidence of relapse or disease progression [5].

Regarding primary resistance, attempts to identify KD mutations at diagnosis have been unsuccessful to date because such TKI-resistant subclones exist at levels too low to be detectable using conventional methodologies $[57,58]$. Although the presence of mutations at low levels may or may not predict poor prognosis [59], an expert panel convened by the European LeukemiaNet has nevertheless recommended that newly diagnosed patients with advanced disease be tested for mutations [56].

A more-sensitive technique for detecting TKI-resistant clones has been developed: a multiplexed mass spectrometry assay [60]. This method has been used to detect nilotinib- and/or dasatinib-resistant mutations in patients with imatinib resistance, including clinically relevant mutations that were not detectable by direct sequencing [60]. Validation of this technique for detecting low-level mutations in patients at diagnosis would help guide the most appropriate front-line TKI and, in the case of a multidrug-resistant mutation, consideration of appropriate therapy.

Advances in identifying molecular markers of progression Identification of potentially important disease mediators is an active area of research that employs techniques such as gene microarray profiling and proteomic analysis. An in-depth exploration of the potential biological significance of the molecules identified is beyond the scope of this review. They are nevertheless mentioned to provide a glimpse of what the future may bring in terms of potential prognostic indicators and therapeutic targets.

Microarray profiling has been used to determine whether the specific gene expression at diagnosis can predict the response to TKI treatment [61]. Analysis of CD34+ cells from newly diagnosed, treatment-naive patients with CML-CP has revealed a 75-transcript signature (50 upregulated and 25 downregulated transcripts) that predicted major cytogenetic response at 12 months with an overall accuracy of $87 \%$ - exceeding the predictive ability of the Sokal score [62]. Notably, $62 \%$ of the 
Table 3 Summary of 3-month landmark analyses of selected clinical studies of first-line TKI therapy

\begin{tabular}{|c|c|c|c|c|c|}
\hline \multirow{2}{*}{$\frac{\text { TKI }}{\text { Imatinib }}$} & \multirow{2}{*}{$\begin{array}{l}\text { Study } \\
\text { Hammersmith Hospital [51] }\end{array}$} & \multirow[t]{2}{*}{ Parameter } & \multicolumn{2}{|c|}{$B C R-A B L 1 \%$ (IS) at 3 months } & \multirow[t]{2}{*}{$P$ value } \\
\hline & & & $\leq 9.84 \%(n=211)$ & $>9.84 \%(n=68)$ & \\
\hline & & 8-year OS & $93.3 \%$ & $56.9 \%$ & $<0.001$ \\
\hline & & & $\leq 9.54 \%(n=208)$ & $>9.54 \%(n=71)$ & \\
\hline & & 8-year PFS & $92.8 \%$ & $57.0 \%$ & $<0.001$ \\
\hline & & & $\leq 8.58 \%(n=169)$ & $>8.58 \%(n=79)$ & \\
\hline & & 8-year CCyR & $99.4 \%$ & $21.7 \%$ & $<0.001$ \\
\hline & & & $\leq 2.81 \%(n=141)$ & $>2.81 \%(n=137)$ & \\
\hline & & 8-year MMR & $82.5 \%$ & $21.1 \%$ & $<0.001$ \\
\hline & German CML Study IV [50] & & $>1-10 \%(n=281)$ & $>10 \%(n=189)$ & \\
\hline & & 5-year OS & $92 \%$ & $87 \%$ & 0.037 \\
\hline & & & $>1-10 \%(n=283)$ & $>10 \%(n=191)$ & \\
\hline & & 5-year PFS & $94 \%$ & $87 \%$ & 0.012 \\
\hline & ENESTnd $^{\mathrm{a}}[52]$ & & $\leq 10 \%(n=176)$ & $>10 \%(n=88)$ & \\
\hline & & MMR by 2 years & $58 \%$ & $21 \%$ & NR \\
\hline & & PFS at 3 years & $97.7 \%$ & $83.8 \%$ & \\
\hline & & OS at 3 years & $98.9 \%$ & $84.8 \%$ & \\
\hline & DASISION $^{\mathrm{a}}[9]$ & & $\leq 10 \%(n=154)$ & $>10 \%(n=85)$ & \\
\hline & & $\mathrm{AP} / \mathrm{BC}$ by 3 years & $2.6 \%$ & $12.9 \%$ & NR \\
\hline & & PFS at 3 years & $95.9 \%$ & $75.3 \%$ & $<0.0001$ \\
\hline & & OS at 3 years & $96.0 \%$ & $88.0 \%$ & 0.0036 \\
\hline & $\mathrm{BELA}^{\mathrm{a}}[53]$ & & $\leq 10 \%(n=146)$ & $>10 \%(n=77)$ & \\
\hline & & MMR by 24 months & $69 \%$ & $17 \%$ & $<0.001$ \\
\hline & & CCyR by 12 months & $95 \%$ & $65 \%$ & $<0.001$ \\
\hline & & OS at 24 months & $99 \%$ & $95 \%$ & NS \\
\hline \multirow[t]{4}{*}{ Nilotinib } & ENESTnd [52] & & $\leq 10 \%(n=234)$ & $>10 \%(n=24)$ & \\
\hline & & MMR by 2 years & $80 \%$ & $29 \%$ & NR \\
\hline & & PFS at 3 years & $95.9 \%$ & $82.9 \%$ & \\
\hline & & OS at 3 years & $97.6 \%$ & $86.7 \%$ & \\
\hline \multirow[t]{4}{*}{ Dasatinib } & DASISION [9] & & $\leq 10 \%(n=198)$ & $>10 \%(n=37)$ & \\
\hline & & $\mathrm{AP} / \mathrm{BC}$ by 3 years & $3.0 \%$ & $13.5 \%$ & NR \\
\hline & & PFS at 3 years & $93.1 \%$ & $68.2 \%$ & 0.0003 \\
\hline & & OS at 3 years & $95.9 \%$ & $85.9 \%$ & 0.0348 \\
\hline \multirow[t]{4}{*}{ Bosutinib } & BELA [53] & & $\leq 10 \%(n=179)$ & $>10 \%(n=29)$ & \\
\hline & & MMR by 24 months & $74 \%$ & $21 \%$ & $<0.001$ \\
\hline & & CCyR by 12 months & $96 \%$ & $48 \%$ & $<0.001$ \\
\hline & & OS at 24 months & $99 \%$ & $88 \%$ & 0.004 \\
\hline
\end{tabular}

${ }^{\mathrm{a}}$ Data for the imatinib arm of the study.

$A P / B C$ accelerated phase/blast crisis, CCyR complete cytogenetic response, MMR major molecular reponse, NR not reported, NS not significant, OS overall survival, PFS progression-free survival.

upregulated transcripts were potential targets of the WNT/ $\beta$-catenin pathway, which is activated during BC. Thus, gene expression profiling at diagnosis may be useful for identifying poor-prognosis patients and for elucidating the biological basis of CML disease progression [62].

Radich et al. used gene microarrays to explore what changes in gene expression are associated with progression to $\mathrm{AP} / \mathrm{BC}$. Their group identified components of the $\mathrm{WNT} / \beta$-catenin pathway and alternative kinase pathways, transcription factors $J U N-B$ and FOS, and the marker PRAME as being associated with advanced CML [63]. Further research identified a 6-gene signature (NOB1, DDX47, IGSF2, LTB4R, SCARB1, and $S L C 25 A 3)$ that discriminated between patients in CP and those in $\mathrm{BC}$ [64]. A second 6-gene signature (RALGDS, 


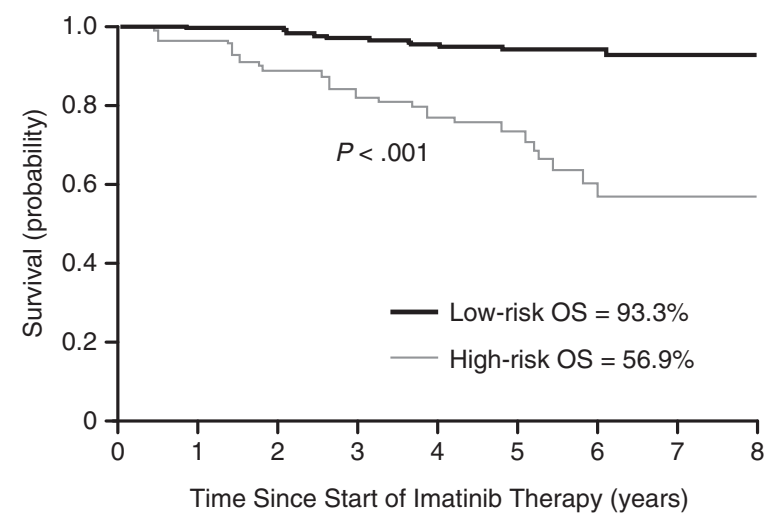

Figure 1 Transcript levels predict survival outcomes. Eight-year probability of OS for patients stratified by risk group defined by transcript levels at 3 months (high-risk BCR-ABL1/ABL1 ratio $>9.84 \%$ $[n=68$; gray line]; low-risk $B C R-A B L 1 / A B L 1 \leq 9.84 \%[n=211$; black line]). From Marin et al. [51] (reproduced with permission).

LASP1, G6PD, ADRBK1, LRPPRC, and PSMA1) has been identified that can predict relapse in patients with CMLCP [65].

Proteomic analysis has identified a group of proteins expressed at low levels in CML-CP but at high levels in CML-BC: HSP90, RB, AIF, PP2A, BCL2, XIAP, SMAD1, SSBP2 $\alpha$, PARP, GAB2, and TRIM24. A reverse pattern, high levels in CML-CP but low levels in $\mathrm{BC}$, has been found for PKC.p664, АKTpT308, actin, p70S6Kp, Rac1.2.3, PDK1p, MEK, and CDK4 [66].

Other approaches have targeted known genes important in proliferation, differentiation, or cell survival. One study found increased expression of CaMKII $\gamma$ and HSP70, but decreased expression of HSP90, in patients with KD mutations compared to those without. Using this expression pattern, the likelihood of TKI-treated patients harboring resistant KD mutations could be predicted with a specificity of $82 \%$ [67]. These and other efforts are underway to further relate molecular markers to progression, with the hope that a greater understanding of their expression will help guide optimal treatment decisions.

\section{Conclusions}

With the approval and availability of 3 front line TKIs and 2 additional TKIs after failure of previous ones for the treatment of CML, prognostic indicators to guide treatment selection have become increasingly important. Given the early state of research, there are few factors that can guide TKI selection. However, knowledge regarding diagnostic systems and genetic, molecular, and pharmacokinetic markers is advancing rapidly. Ongoing work continues to illuminate the pathways and genes that could serve both as prognostic indicators and as targets for drug development.
Convincing data are emerging that early and deep molecular responses are associated with excellent long-term outcomes. Patients who do not attain such responses have poorer prognosis and may benefit from an early change in treatment. Collectively, this abundance of knowledge suggests that we should someday be able to pinpoint the optimal treatment for each individual patient.

\section{Abbreviations}

ABL1: Abelson 1 gene; ACA: Additional cytogenetic aberration; ADRBK1: Adrenergic, beta, receptor kinase 1; AlF: Apoptosis-inducing factor; AKT: Derived from "thymoma arising in the Ak strain of mice"; AP: Accelerated phase; BC: Blast crisis; BCL2: B-cell chronic lymphocytic leukemia/lymphoma 2; BCR: Breakpoint cluster region; BELA: Bosutinib Efficacy and Safety in Newly Diagnosed CML; CCyR: Complete cytogenetic response; CDK4: Cyclin-dependent kinase 4; CML: Chronic myelogenous leukemia; CMR: Complete molecular response; CP: Chronic phase; DASISION: Dasatinib versus Imatinib Study in Treatment-Naive CML Patients; DDX47: DEAD (Asp-Glu-Ala-Asp) box polypeptide 47; EFS: Event-free survival; ENESTnd: Evaluating Nilotinib Efficacy and Safety in Clinical Trials-Newly Diagnosed Patients; EUTOS: European Treatment and Outcome Study; FOS: FBJ osteosarcoma oncogene; G6PD: Glucose-6-phosphate dehydrogenase; GAB2: GRB2 (growth factor receptor-bound protein 2)-associated binding protein 2; HSP: Heat shock protein;

IGSF2: Immunoglobulin superfamily, member 2; IRIS: International Randomized Study of Interferon and STI571; IS: International scale/ DefinitionListEntry $>J U N-B$ : Protooncogene originally identified as the transforming factor in avian sarcoma virus 17; KD: Kinase domain; LASP1: LIM and SH3 (Src homology region 3) protein 1; LRPPRC: Leucine-rich pentatricopeptide repeat containing; LTB4R: Leukotriene B4 receptor; MEK: Mitogen-activated protein kinase (MAPK) kinase; MMR: Major molecular response; NOB1: NIN1/RPN12 binding protein 1; OCT-1: Organic cation transporter-1; OS: Overall survival; PARP: Poly (ADP-ribose) polymerase; PDK1: Pyruvate dehydrogenase kinase, isozyme 1; PFS: Progression-free survival; Ph+: Philadelphia chromosome-positive; PKC: Protein kinase $C_{i}$ PP2A: Protein phosphatase 2A; PRAME: Preferentially expressed antigen in melanoma; PSMA1: Proteasome subunit, alpha type, 1; RALGDS: Ral guanine nucleotide dissociation stimulator; RB: Retinoblastoma; SCARB1: Scavenger receptor class B, member 1; SLC25A3: Solute carrier family 25, member 3 ; SMAD1: Portmanteau of $C$. elegans small body size (sma) and $D$. melanogaster mothers against decapentaplegic (MAD); SSBP2a: Singlestranded DNA binding protein 2a; TKI: Tyrosine kinase inhibitor; TRIM24: Tripartite motif containing 24; WNT: Portmanteau of D. melanogaster wingless (Wg) and mammalian integration 1 (Int1); XIAP: X-linked inhibitor of apoptosis.

\section{Competing interests}

Conflict of interest disclosures: Dr. Pinilla-lbarz has received honoraria from Novartis and Bristol-Myers Squibb and research support from Novartis, Bristol-Myers Squibb, and Ariad. Drs. Sweet and Zhang have no conflicts to report.

\section{Authors' contributions}

LZ and JPI conceived of the topics of discussion. All authors helped draft the manuscript, critically reviewed and revised the manuscript, and read and approved the final manuscript.

\section{Acknowledgments}

Financial support for medical editorial assistance was provided by Novartis Pharmaceuticals Corporation. We thank Mariana Ovnic, PhD, and Anna Lau, PhD, of Percolation Communications LLC for medical editorial assistance.

\section{Funding}

Funding source: Financial support for medical editorial assistance was provided by Novartis Pharmaceuticals Corporation.

Received: 28 March 2013 Accepted: 19 June 2013

Published: 19 July 2013 


\section{References}

1. Deininger MW, Goldman JM, Melo JV: The molecular biology of chronic myeloid leukemia. Blood 2000, 96(10):3343-3356.

2. Baccarani M, Castagnetti F, Gugliotta G, Palandri F, Soverini S: Response definitions and European Leukemianet Management recommendations. Best Pract Res Clin Haematol 2009, 22(3):331-341.

3. Novartis Pharmaceuticals Corporation: Gleevec (imatinib mesylate) [prescribing information]. East Hanover, NJ: Novartis Pharmaceuticals Corporation; 2009.

4. Gambacorti-Passerini C, Valletta S, Stasia A, Leeksma A, Sharma N, Rizzo C, Pogliani EM, Pirola A, Piazza R: CML patients present additional mutations in cancer related genes when tested at diagnosis [abstract]. Blood (ASH Annual Meeting Abstracts) 2011, 118(21):2739.

5. NCCN Clinical Practice Guidelines in Oncology: Chronic myelogenous leukemia. Version 4.2013 http://www.nccn.org/professionals/physician_gls/pdf/cml.pdf.

6. Bristol-Myers Squibb Company: Sprycel (dasatinib) [prescribing information]. Princeton, NJ: Bristol-Myers Squibb Company; 2013.

7. Kantarjian H, Shah NP, Hochhaus A, Cortes J, Shah S, Ayala M, Moiraghi B, Shen Z, Mayer J, Pasquini R, Nakamae H, Huguet F, Boque C, Chuah C, Bleickardt E, Bradley-Garelik MB, Zhu C, Szatrowski T, Shapiro D, Baccarani M: Dasatinib versus imatinib in newly diagnosed chronic-phase chronic myeloid leukemia. N Engl J Med 2010, 362(24):2260-2270.

8. Novartis Pharmaceuticals Corporation: Tasigna (nilotinib) [prescribing information]. East Hanover, NJ: Novartis Pharmaceuticals Corporation; 2012. May

9. Saglio G, Kantarjian HM, Shah N, Jabbour EJ, Quintas-Cardama A, Steegmann JL, Boque C, Chuah C, Pavlovsky C, Mayer J, Ukropec J, Wildgust M, Hochhaus A: Early response (molecular and cytogenetic) and longterm outcomes in newly diagnosed chronic myeloid leukemia in chronic phase (CML-CP): Exploratory analysis of DASISION 3-year data [abstract]. Blood (ASH Annual Meeting Abstracts) 2012, 120(21):1675.

10. Kantarjian HM, Hochhaus A, Saglio G, De Souza C, Flinn IW, Stenke L, Goh YT, Rosti G, Nakamae H, Gallagher NJ, Hoenekopp A, Blakesley RE, Larson RA, Hughes TP: Nilotinib versus imatinib for the treatment of patients with newly diagnosed chronic phase, Philadelphia chromosome-positive, chronic myeloid leukaemia: 24-month minimum follow-up of the phase 3 randomised ENESTnd trial. Lancet Oncol 2011, 12(9):841-851.

11. Kantarjian H, Flinn IW, Goldberg S, Bunworasate U, Zanichelli MA, Nakamae H, Hughes TP, Hochhaus A, Saglio G, Woodman RC, Blakesley RE, Kemp CN, Kalaycio ME, Larson RA: Nilotinib versus imatinib in patients (pts) with newly diagnosed chronic myeloid leukemia in chronic phase (CML-CP): ENESTnd 3-year (yr) follow-up (f/u) [abstract]. J Clin Oncol (ASCO Annual Meeting Abstracts) 2012, 30(suppl):6509.

12. Hochhaus A, Shah NP, Cortes JE, Baccarani M, Bradley-Garelik MB, Dejardin $D$, Kantarjian H: Dasatinib versus imatinib (IM) in newly diagnosed chronic myeloid leukemia in chronic phase (CML-CP): DASISION 3-year follow-up [abstract]. J Clin Oncol (ASCO Annual Meeting Abstracts) 2012, 30(suppl):6504.

13. Sokal JE, Cox EB, Baccarani M, Tura S, Gomez GA, Robertson JE, Tso CY, Braun TJ, Clarkson BD, Cervantes F: Prognostic discrimination in "good-risk" chronic granulocytic leukemia. Blood 1984, 63(4):789-799.

14. Hasford J, Pfirrmann M, Hehlmann R, Allan NC, Baccarani M, Kluin-Nelemans $J C$, Alimena G, Steegmann JL, Ansari H: A new prognostic score for survival of patients with chronic myeloid leukemia treated with interferon alfa. Writing Committee for the Collaborative CML Prognostic Factors Project Group. J Natl Cancer Inst 1998, 90(11):850-858.

15. Hasford J, Baccarani M, Hoffmann V, Guilhot J, Saussele S, Rosti G, Guilhot F, Porkka K, Ossenkoppele G, Lindoerfer D, Simonsson B, Pfirrmann M, Hehlmann R: Predicting complete cytogenetic response and subsequent progression-free survival in 2060 patients with CML on imatinib treatment: the EUTOS score. Blood 2011, 118(3):686-692.

16. Saussele S, Lauseker M, Hoffmann V, Proetel U, Hanfstein B, Baerlocher GM, Heim D, Ehninger G, Hossfeld DK, Kolb H-J, Krause SW, Nerl C, Pralle H, Schubert JEA, Einsele H, Hanel M, Ho AD, Falge C, Kanz L, Neubauer A, Kneba M, Stegelmann F, Pfreundschuh M, Waller CF, Spiekermann K, Schnittger S, Pfirrmann M, Hochhaus A, Hasford J, Hehlmann R, et al: Prediction of molecular response of chronic phase CML patients by the EUTOS score: results of the randomized CML-Study IV [abstract]. Blood (ASH Annual Meeting Abstracts) 2011, 118(21):3762.

17. Marin D, Ibrahim AR, Goldman JM: European Treatment and Outcome Study (EUTOS) score for chronic myeloid leukemia still requires more confirmation. J Clin Oncol 2011, 29(29):3944-3945.
18. Jabbour E, Cortes J, Nazha A, O'Brien S, Quintas-Cardama A, Pierce S, Garcia-Manero G, Kantarjian H: EUTOS score is not predictive for survival and outcome in patients with early chronic phase chronic myeloid leukemia treated with tyrosine kinase inhibitors: a single institution experience. Blood 2012, 119(19):4524-4526.

19. Kantarijan HM, Shah NP, Cortes JE, Baccarani M, Agarwal MB, Undurraga MS, Wang J, Ipina JJ, Kim DW, Ogura M, Pavlovsky C, Junghanss C, Milone JH, Nicolini FE, Robak T, Van Droogenbroeck J, Vellenga E, Bradley-Garelik MB, Zhu C, Hochhaus A: Dasatinib or imatinib in newly diagnosed chronic-phase chronic myeloid leukemia: 2-year follow-up from a randomized phase 3 trial (DASISION). Blood 2012, 119(5):1123-1129.

20. Cortes JE, Kim DW, Kantarjian HM, Brummendorf TH, Dyagil I, Griskevicus L Malhotra H, Powell C, Gogat K, Countouriotis AM, Gambacorti-Passerini C Bosutinib versus imatinib in newly diagnosed chronic-phase chronic myeloid leukemia: results from the BELA Trial. J Clin Oncol 2012, 30(28):3486-3492.

21. Trask P, Mitra D, lyer S, Candrilli S, Kaye J: Patterns and prognostic indicators of response to CML treatment in a multi-country medical record review study. Int J Hematol 2012, 95(5):535-544.

22. Saglio G, Kim DW, Issaragrisil S, Le Coutre P, Etienne G, Lobo C, Pasquini R, Clark RE, Hochhaus A, Hughes TP, Gallagher N, Hoenekopp A, Dong M, Haque A, Larson RA, Kantarjian HM: Nilotinib versus imatinib for newly diagnosed chronic myeloid leukemia. N Engl J Med 2010, 362(24):2251-2259.

23. Verma D, Kantarijan H, Shan J, O'Brien S, Estrov Z, Garcia-Manero G, Koller C, Borthakur G, Cortes J: Survival outcomes for clonal evolution in chronic myeloid leukemia patients on second generation tyrosine kinase inhibitor therapy. Cancer 2010, 116(11):2673-2681.

24. Fabarius A, Leitner A, Hochhaus A, Muller MC, Haferlach C, Gohring G, Schlegelberger B, Jotterand M, Reiter A, Jung-Munkwitz $S$, Proetel $U$, Schwaab J, Hofmann W-K, Schubert JEA, Einsele H, Ho AD, Falge C, Kanz L, Neubauer A, Kneba M, Stegelmann F, Pfreundschuh M, Waller CF, Hiddemann W, Baerlocher GM, Lauseker M, Pfirrmann M, Saussele S, Hehlmann R, Hasford J: Impact of additional cytogenetic alterations at diagnosis on prognosis of CML: long-term observation from 1151 patients of the randomized CML Study IV [abstract]. Blood (ASH Annual Meeting Abstracts) 2011, 118(21):782.

25. Cortes JE, Talpaz M, Giles F, O'Brien S, Rios MB, Shan J, Garcia-Manero G, Faderl S, Thomas DA, Wierda W, Ferrajoli A, Jeha S, Kantarjian HM: Prognostic significance of cytogenetic clonal evolution in patients with chronic myelogenous leukemia on imatinib mesylate therapy. Blood 2003, 101(10):3794-3800.

26. Kim TD, Turkmen S, Schwarz M, Koca G, Nogai H, Bommer C, Dorken B, Daniel P, Le Coutre P: Impact of additional chromosomal aberrations and $B C R-A B L$ kinase domain mutations on the response to nilotinib in Philadelphia chromosome-positive chronic myeloid leukemia. Haematologica 2010, 95(4):582-588.

27. Lahaye T, Riehm B, Berger U, Paschka P, Muller MC, Kreil S, Merx K, Schwindel U, Schoch C, Hehlmann R, Hochhaus A: Response and resistance in 300 patients with BCR-ABL-positive leukemias treated with imatinib in a single center: a 4.5-year follow-up. Cancer 2005, 103(8):1659-1669.

28. Albano F, Anelli L, Zagaria A, Coccaro N, Casieri P, Rossi AR, Vicari L, Liso V, Rocchi M, Specchia G: Non random distribution of genomic features in breakpoint regions involved in chronic myeloid leukemia cases with variant $\mathrm{t}(9 ; 22)$ or additional chromosomal rearrangements. Mol Cancer 2010, 9:120.

29. Brahmbhatt MM, Trivedi PJ, Dalal EN, Patel DM, Purani SS, Shukla SN, Shah PM, Patel PS: ABL/BCR gene variant with two-step mechanism: Unusual localization and rare/novel chromosomal rearrangements in CML patients. J Assoc Genet Technol 2011, 37(2):69-75.

30. El-Zimaity MM, Kantarjian H, Talpaz M, O'Brien S, Giles F, Garcia-Manero G, Verstovsek S, Thomas D, Ferrajoli A, Hayes K, Nebiyou Bekele B, Zhou X, Rios $M B$, Glassman AB, Cortes JE: Results of imatinib mesylate therapy in chronic myelogenous leukaemia with variant Philadelphia chromosome. BrJ Haematol 2004, 125(2):187-195.

31. Valencia A, Cervera J, Such E, Barragan E, Bolufer P, Fuster O, Collado R, Martinez J, Sanz MA: Complex variant $\mathrm{t}(9 ; 22)$ chromosome translocations in five cases of chronic myeloid leukemia. Adv Hematol 2009, 2009:187125.

32. Stagno F, Vigneri P, Del Fabro V, Stella S, Cupri A, Massimino M, Consoli C, Tambe L, Consoli ML, Antolino A, Di Raimondo F: Influence of complex 
variant chromosomal translocations in chronic myeloid leukemia patients treated with tyrosine kinase inhibitors. Acta Oncol 2010, 49(4):506-508

33. Tantiworawit A, Abou Mourad Y, Barnett MJ, Broady R, Hogge DE, Nantel SH, Narayanan S, Nevill TJ, Power MM, Shepherd JD, Song KW, Sutherland $\mathrm{HJ}$, Toze CL, Forrest DL: Clonal evolution but not variant chromosomal translocations is an adverse prognostic marker for cytogenetic response and survival in CML patients treated with imatinib [abstract]. Blood (ASH Annual Meeting Abstracts) 2011, 118(21):1694.

34. Gorusu M, Benn P, Li Z, Fang M: On the genesis and prognosis of variant translocations in chronic myeloid leukemia. Cancer Genet Cytogenet 2007, 173(2):97-106.

35. Shah BD, Zhang L, Bulkeley W, Moscinski L, Papenhausen P, Pinilla-lbarz J: Outcome of complex variant Philadelphia positive chromosome translocations in the era of tyrosine kinase inhibitors [abstract]. Blood (ASH Annual Meeting Abstracts) 2011, 118(21):3788.

36. Hehlmann R, Hanfstein B, Muller MC, Erben P, Lauseker M, Fabarius A, Schnittger S, Haferlach C, Goehring G, Krause SW, Dengler J, Falge C, Neubauer A, Stegelmann F, Pfeundschuh M, Spiekermann K, Baerlocher GM, Hasford J, Saussele S, Hochhaus A: Group AftSatGCS: The prognostic significance of early molecular and cytogenetic response for long-term progression-free and overall survival in imatinib-treated chronic myeloid leukemia (CML) [abstract]. J Clin Oncol 2012, 30(15 suppl):6510.

37. Lucas CM, Harris RJ, Giannoudis A, Davies A, Knight K, Watmough SJ, Wang L, Clark RE: Chronic myeloid leukemia patients with the e13a2 BCR-ABL fusion transcript have inferior responses to imatinib compared to patients with the e14a2 transcript. Haematologica 2009, 94(10):1362-1367.

38. Hanfstein B, Erben P, Saussele S, Lauseker M, Proetel U, Haag S, Schnittger S, Haferlach C, Kolb H-J, Krause SW, Nerl C, Heim D, Baerlocher GM, Schubert JEA, Einsele H, Hanel M, Dengler J, Falge C, Kanz L, Neubauer A, Kneba M, Stegelmann F, Pfreundschuh M, Waller CF, Pfirrmann M, Hasford J, Hofmann W-K, Hehlmann R, Hochhaus A, Muller MC, et al: Distinct characteristics of e13a2 versus e14a2 BCR-ABL chronic myeloid leukemia under upfront treatment with imatinib - an analysis of the German CML Study IV [abstract]. Blood (ASH Annual Meeting Abstracts) 2011, 118(21):3773.

39. White DL, Saunders VA, Dang P, Engler J, Zannettino AC, Cambareri AC, Quinn SR, Manley PW, Hughes TP: OCT-1-mediated influx is a key determinant of the intracellular uptake of imatinib but not nilotinib (AMN107): reduced OCT-1 activity is the cause of low in vitro sensitivity to imatinib. Blood 2006, 108(2):697-704.

40. White DL, Dang P, Engler J, Frede A, Zrim S, Osborn M, Saunders VA, Manley PW, Hughes TP: Functional activity of the OCT-1 protein is predictive of long-term outcome in patients with chronic-phase chronic myeloid leukemia treated with imatinib. J Clin Oncol 2010, 28(16):2761-2767.

41. Hiwase DK, Saunders V, Hewett D, Frede A, Zrim S, Dang P, Eadie L, To LB, Melo J, Kumar S, Hughes TP, White DL: Dasatinib cellular uptake and efflux in chronic myeloid leukemia cells: therapeutic implications. Clin Cancer Res 2008, 14(12):3881-3888.

42. ARIAD Pharmaceuticals, Inc: Iclusig (ponatinib) [prescribing information]. Cambridge, MA: ARIAD Pharmaceuticals, Inc; 2012.

43. Pfizer Labs: Bosulif (bosutinib) [prescribing information]. New York, NY: Pfizer Labs; 2012.

44. Picard S, Titier K, Etienne G, Teilhet E, Ducint D, Bernard MA, Lassalle R, Marit G, Reiffers J, Begaud B, Moore N, Molimard M, Mahon FX: Trough imatinib plasma levels are associated with both cytogenetic and molecular responses to standard-dose imatinib in chronic myeloid leukemia. Blood 2007, 109(8):3496-3499.

45. Larson RA, Druker BJ, Guilhot F, O'Brien SG, Riviere GJ, Krahnke T, Gathmann I, Wang Y: Imatinib pharmacokinetics and its correlation with response and safety in chronic-phase chronic myeloid leukemia: a subanalysis of the IRIS study. Blood 2008, 111(8):4022-4028.

46. Faber E, Friedecky D, Micova K, Rozmanova S, Divoka M, Jarosova M, Indrak K, Adam T: Imatinib trough plasma levels do not correlate with the response to therapy in patients with chronic myeloid leukemia in routine clinical setting. Ann Hematol 2012, 91(6):923-929.

47. Koren-Michowitz M, Volchek Y, Naparstek E, Gavish I, Levi I, Rowe JM, Shimoni A, Nagler A: Imatinib plasma trough levels in chronic myeloid leukaemia: results of a multicentre study CSTI571AIL11TGLIVEC. Hematol Oncol 2012, 30(4):200-205.

48. Sohn SK, Oh SJ, Kim BS, Ryoo HM, Chung JS, Joo YD, Bang SM, Jung CW, Kim DH, Yoon SS, Kim H, Lee HG, Won JH, Min YH, Cheong JW, Park JS,
Eom KS, Hyun MS, Kim MK, Park MR, Park J, Kim CS, Kim HJ, Kim YK, Park EK, Zang DY, Jo DY, Moon JH, Park SY: Trough plasma imatinib levels are correlated with optimal cytogenetic responses at 6 months after treatment with standard dose of imatinib in newly diagnosed chronic myeloid leukemia. Leuk Lymphoma 2011, 52(6):1024-1029.

49. Hughes TP, Hochhaus A, Branford S, Muller MC, Kaeda JS, Foroni L, Druker BJ, Guilhot F, Larson RA, O'Brien SG, Rudoltz MS, Mone M, Wehrle E, Modur V, Goldman JM, Radich JP: Long-term prognostic significance of early molecular response to imatinib in newly diagnosed chronic myeloid leukemia: an analysis from the International Randomized Study of Interferon and STI571 (IRIS). Blood 2010, 116(19):3758-3765.

50. Hanfstein B, Muller MC, Hehlmann R, Erben P, Lauseker M, Fabarius A, Schnittger S, Haferlach C, Gohring G, Proetel U, Kolb HJ, Krause SW, Hofmann WK, Schubert J, Einsele H, Dengler J, Hanel M, Falge C, Kanz L, Neubauer A, Kneba M, Stegelmann F, Pfreundschuh M, Waller CF, Branford S, Hughes TP, Spiekermann K, Baerlocher GM, Pfirrmann M, Hasford J, et al: Early molecular and cytogenetic response is predictive for long-term progression-free and overall survival in chronic myeloid leukemia (CML). Leukemia 2012, 26(9):2096-2102.

51. Marin D, Ibrahim AR, Lucas C, Gerrard G, Wang L, Szydlo RM, Clark RE, Apperley JF, Milojkovic D, Bua M, Pavlu J, Paliompeis C, Reid A, Rezvani K, Goldman JM, Foroni L: Assessment of BCR-ABL1 transcript levels at 3 months is the only requirement for predicting outcome for patients with chronic myeloid leukemia treated with tyrosine kinase inhibitors. J Clin Oncol 2012, 30(3):232-238.

52. Hochhaus A, Hughes TP, Saglio G, Guilhot F, Al-Ali HK, Rosti G, Nakaseko C, De Souza CA, Kemp C, Fan X, Hoenekopp A, Larson RA, Kantarjian HM: Outcome of patients with chronic myeloid leukemia in chronic phase (CML-CP) based on early molecular response and factors associated with early response: 4-year follow-up data from ENESTnd (Evaluating Nilotinib Efficacy and Safety in Clinical Trials Newly Diagnosed Patients) [abstract]. Blood (ASH Annual Meeting Abstracts) 2012, 120(21):167.

53. Brummendorf TH, Kantarjian HM, Gambacorti-Passerini C, Guilhot F, Akard L, Doshi V, Lipton JH, Pavlov D, Gogat K, Duvillie L, Shapiro M, Cortes JE: Assessment of early molecular response as a predictor of long-term clinical outcomes in the phase 3 BELA Study [abstract]. Blood (ASH Annual Meeting Abstracts) 2012, 120(21):69

54. Naqvi K, Kantarjian HM, Luthra R, Jabbour E, O'Brien S, Burton EM, Verstovsek S, Ravandi F, Wierda WG, Borthakur G, Quintas-Cardama A Cortes JE: Kinetics of molecular response with different tyrosine kinase inhibitors (TKI) used as frontline therapy in chronic myeloid leukemia-chronic phase (CML CP) [abstract]. Blood (ASH Annual Meeting Abstracts) 2011, 118(21):3784

55. Nicolini FE, Hayette S, Labussiere H, Etienne M, Fort M-P, Gadolet E, Tigaud I, Chabane K, Lippert E, Sobh M, Dulucq S, Morisset S, Michallet M, Mahon F-X Etienne G: The month three major molecular response in chronic phase chronic myeloid leukemia on imatinib 400, nilotinib and dasatinib is a major prognostic factor for failure-free and progression-free survival [abstract]. Blood (ASH Annual Meeting Abstracts) 2011, 118(21):1684

56. Soverini S, Hochhaus A, Nicolini FE, Gruber F, Lange T, Saglio G, Pane F, Muller MC, Ernst T, Rosti G, Porkka K, Baccarani M, Cross NC, Martinelli G: BCR-ABL kinase domain mutation analysis in chronic myeloid leukemia patients treated with tyrosine kinase inhibitors: recommendations from an expert panel on behalf of European LeukemiaNet. Blood 2011, 118(5):1208-1215.

57. Soverini S, Martinelli G, Rosti G, Bassi S, Amabile M, Poerio A, Giannini B, Trabacchi E, Castagnetti F, Testoni N, Luatti S, De Vivo A, Cilloni D, Izzo B, Fava M, Abruzzese E, Alberti D, Pane F, Saglio G, Baccarani M: ABL mutations in late chronic phase chronic myeloid leukemia patients with up-front cytogenetic resistance to imatinib are associated with a greater likelihood of progression to blast crisis and shorter survival: a study by the GIMEMA Working Party on Chronic Myeloid Leukemia. J Clin Oncol 2005, 23(18):4100-4109.

58. Willis SG, Lange T, Demehri S, Otto S, Crossman L, Niederwieser D, Stoffregen EP, McWeeney S, Kovacs I, Park B, Druker BJ, Deininger MW: High-sensitivity detection of BCR-ABL kinase domain mutations in imatinib-naive patients: correlation with clonal cytogenetic evolution but not response to therapy. Blood 2005, 106(6):2128-2137.

59. Soverini S, Gnani A, De Benedittis C, Castagnetti F, Gugliotta G, lacobucci I, Palandri F, Rosti G, Testoni N, Luatti S, Marzocchi G, Baccarani M, Martinelli $\mathrm{G}$ : Low-level Bcr-Abl mutations are very rare in chronic myeloid leukemia 
patients who are in major molecular response on first-line nilotinib. Leuk Res 2011, 35(11):1527-1529.

60. Parker WT, Lawrence RM, Ho M, Irwin DL, Scott HS, Hughes TP, Branford S: Sensitive detection of BCR-ABL1 mutations in patients with chronic myeloid leukemia after imatinib resistance is predictive of outcome during subsequent therapy. J Clin Oncol 2011, 29(32):4250-4259.

61. Yong AS, Melo JV: The impact of gene profiling in chronic myeloid leukaemia. Best Pract Res Clin Haematol 2009, 22(2):181-190.

62. McWeeney SK, Pemberton LC, Loriaux MM, Vartanian K, Willis SG, Yochum G, Wilmot B, Turpaz Y, Pillai R, Druker BJ, Snead JL, MacPartlin M, O'Brien SG, Melo JV, Lange T, Harrington CA, Deininger MW: A gene expression signature of CD34+ cells to predict major cytogenetic response in chronic-phase chronic myeloid leukemia patients treated with imatinib. Blood 2010, 115(2):315-325.

63. Radich JP, Dai H, Mao M, Oehler V, Schelter J, Druker B, Sawyers C, Shah N, Stock W, Willman CL, Friend S, Linsley PS: Gene expression changes associated with progression and response in chronic myeloid leukemia. Proc Natl Acad Sci USA 2006, 103(8):2794-2799.

64. Oehler VG, Yeung KY, Choi YE, Bumgarner RE, Raftery AE, Radich JP: The derivation of diagnostic markers of chronic myeloid leukemia progression from microarray data. Blood 2009, 114(15):3292-3298.

65. Yeung KY, Gooley TA, Zhang A, Raftery AE, Radich JP, Oehler VG: Predicting relapse prior to transplantation in chronic myeloid leukemia by integrating expert knowledge and expression data. Bioinformatics 2012, 28(6):823-830.

66. Quintas-Cardama A, Qiu YH, Post S, Zhang Y, Creighton C, Cortes JE, Kornblau SM: Proteomic profiling of 112 proteins in chronic myeloid leukemia patient samples using reverse phase proteins arrays (RPPA) reveals distinct protein expression signatures associated with advanced phase disease and the CD34+ compartment [abstract]. Blood (ASH Annual Meeting Abstracts) 2011, 118(21):2503.

67. Gonzalez MS, De Brasi CD, Bianchini M, Ferri C, Bengio R, Larripa IB: Expression of CAMKIly, HSP70 and HSP90 genes are differentially associated with the mutational status of tirosine kinase domain in chronic myeloid leukemia resistant patients [abstract]. Blood (ASH Annual Meeting Abstracts) 2011, 118(21):4877.

doi:10.1186/1756-8722-6-54

Cite this article as: Sweet et al:: Biomarkers for determining the prognosis in chronic myelogenous leukemia. Journal of Hematology \& Oncology 2013 6:54.

\section{Submit your next manuscript to BioMed Central and take full advantage of:}

- Convenient online submission

- Thorough peer review

- No space constraints or color figure charges

- Immediate publication on acceptance

- Inclusion in PubMed, CAS, Scopus and Google Scholar

- Research which is freely available for redistribution 